\title{
1. Country, Native Title and Ecology ${ }^{1}$
}

\author{
Jessica K Weir
}

The overtly technical process of making a native title application has obscured one of the central reasons why Indigenous people engage with the native title system - to affirm and promote their relationships with country. This publication focuses on Indigenous peoples' relationships with country, and seeks to discuss native title in terms that are more directly related to those relationships. In doing so, we also describe ways of living on country that inform and critique mainstream land and water management. This volume also includes case studies that are not classified as part of the native title system, so as to broaden native title issues into the frame of traditional ownership. Limitations with common and statutory native title law have meant that native title is not a land justice system accessible to all traditional owners of country. Profound connection to country frequently exists where native title cannot be successfully applied for, or where traditional owners choose not to make native title applications.

The focus in this volume on native title and ecology is made because many traditional owners express their attachment for country through their unique ecologies, and the discipline of ecology's focus on relationships links into the holistic language of country. Framing native title with ecological thinking also deliberately challenges the contributing authors to resist being led by the law, culture and bureaucracy of native title. Instead, we bring our attention to issues of land and water, the relationships Indigenous people hold with species and their ecologies, and the challenges and opportunities of native title to sustain life.

Currently, academics are rethinking their disciplines and knowledge traditions in response to environmental devastation, to consider why we are not better able to value and respond to our ecological relationships. The wider significance of this work is to consider how we should live in this time of global climate change and widespread environmental destruction. In Australia, this intellectual rethink is informed by Indigenous peoples' knowledge about country. Indigenous people have knowledge systems and concepts, territories, cultures and customary activities centred on living with country. In recent times, this inheritance has been interacting with the laws, knowledges, cultures and customs introduced by non-Indigenous people. This intercultural context highlights the different

1 I would like to thank Luke Taylor, Tran Tran and two anonymous peer reviewers for their comments on an earlier version of this paper. For their editorial assistance I thank Leah Ginnivan, Lydia Glick, Geoff Hunt, Claire Stacey, and Cynthia Ganesharajah. 
and similar cultural concerns that Indigenous and non-Indigenous people bring to intellectual frameworks that prioritise the life of country, life which inspires all people to live on and enjoy country.

\section{Countries and ecologies}

Country is a term many Aboriginal people use generally to describe their traditional lands and waters, although it has a much broader meaning than just territory. Riley Young spoke to Deborah Rose about the importance of his country, which includes the Yarralin community in the north of the Northern Territory:

We been borning [in] this country. We been grow up [in] this country. We been walkabout this country. We know all this country all over ... Blackfellow been born top of that ground, and blackfellow-blackfellow blood [in the ground] ... This ground is mother. This ground, she's my mother. She's mother for everybody. We born top of this ground. This [is] our mother. That's why we worry about this ground. (R Young, cited in Rose, 2000 [1992]: 220)

Country can be one's own campfire, one's family area, a clan area, a geographical region, a language area and, or, an ecological zone. Country might be similar to a drainage basin for a river, or be marked by a particular plant species, or not. It depends on the context (Rose, 2000 [1992]: 117). Country is much more dynamic than a people-place match; it is multilayered and indeterminate with multiple forms and meanings (Sutton, 1995: 49-50). One person will have multiple countries, and one country will have multiple people. Because people have multiple affiliations to different countries, they will always be negotiating these relationships over their lifetime.

Many Indigenous people speak about the importance of their country because of who they are and how their way of life is embedded in their country. They continue to live on their country or maintain their links to country through visits and other means. There are also Indigenous people seeking to reconnect with country, including some members of the Stolen Generations. Many Indigenous people live in communities, towns and cities on the country of other people. They are sometimes known as 'historical peoples', in that they moved, or were moved, historically to those lands and have chosen to stay and invest in the new community. 
Country is useful to examine as a philosophy of existence. In its most expansive sense it is where knowledge comes from. Country is where the rules for existence and many of the relationships between species and humans were established by ancestral creative beings (Rose, 2000 [1992]: 43-44). In the Dreaming creative beings travelled over the land creating species and geographical features. The Dreaming is not past or present but 'everywhen' (Stanner, 1989 [1963]: 228). Rose describes what she calls the Dreaming ecology:

Everything comes out of the earth by Dreaming; everything knows itself, its place, its relationships to other portions of the cosmos. Every living thing has, and knows, its own Law. (Rose, 2000 [1992]: 220)

Knowledge, country, species and people are co-created. Country is the locus of this knowledge and ecological life.

Critically, in country humans and nature, and nature and culture, are not regarded as separate, but are entangled together in all types of relationships. Species and their relationships with humans are spoken about in terms of language, law, religion and stories (see, for example, Kinnane, 2002; Langton, 2002; Rose, 1996; Smith, 2005). This knowledge teaches which relationships are important and why, with a focus on life sustaining networks that can also be called 'connectivity' (Weir, 2008). This is an expanded connectivity that goes beyond food and energy webs to encompass stories, histories, feelings, shared responsibilities and respect.

Ecologists use the term connectivity in a narrower sense to describe the way animals and plants are interconnected through energy webs with each other, across places and through time. Ecologists recognise that each species has its own understanding of how to survive where they live, and ecologists call this their ecological niche or habitat (Allen and Hoekstra, 1992: 169; Manning et al., 2004: 622-623). Importantly, ecology has been part of the reinvigoration of science towards more integrated thinking about environmental issues (Worster, 2008 [1997]; see also, Godden, this volume). Ecologists are 'subversive scientists' in their rejection of the atomism of reductive laboratory work (Worster, 2008 [1997]: 22). Ecologists engage with organic complexity and connection within and across ecosystems.

Ecology is often described as a sub-discipline of biology, and the subjectivity of this approach is evident in its history and contemporary context. Biology and ecology are influenced by the 'balance of nature' assumption arising out of seventeenth century Christian theology. In the twentieth century, ecologists debunked the idea of nature as equilibrium, with plants and animals in stable populations, and replaced it with a dynamic focus on energy flow, and plant and animal productivity and succession (Egerton, 1973: 330). Donald Worster 
has followed the evolution of theories about ecosystems, from natural order to complexity, chaos and disorder (Worster, 2008 [1997]: 412). Worster has also described how ecologists find themselves propelled into environmental activism because of the huge rise in species extinctions (2008 [1997]: 419). Together with conservation biologists, ecologists have been at the forefront of documenting and responding to the rapid loss of biodiversity that is occurring in contemporary times (for example Lindenmayer, 2007).

One of the most powerful legacies of the western scientific tradition has been the separation of humans from nature, which developed as a central tenet of the natural sciences. In the conservation tradition this separation is also known as 'wilderness thinking', where a pristine nature exists outside of human activity (Braun, 2002: 2). Wilderness thinking has been replicated in western land tenure systems that separate nature into definable people-free spaces, including national parks, reserved lands, and protected areas. In Australia, these land tenures have excluded Indigenous people from their country. The erasure of Indigenous peoples' rights complicit in these land tenures continues to have ramifications in native title, limiting the kind of native title rights that can be recognised (see discussion below). Human rights infringements resulting from wilderness thinking have forced a rethink of this ideology, to create participatory conservation practices (Campese et al., 2009). In Australia, Indigenous people are now accessing conservation monies as part of managing their native title lands and waters.

The influence of separating humans from nature has also contributed to a rationalist and utilitarian approach to country (Kinnane, 2002: 24). Nature has become natural resources, simplified as matter that is external to humans and for human consumption (Braun, 2002: 41; Robin, 2007: 186). Combined with the achievements of the industrial revolution, separation thinking has enabled proponents to transform nature on a massive scale, without regard for the delicate web of relations which bind together all creatures (Latour, 2001 [1993]: 32, 39). In the academic response to ecological devastation, ecologists, anthropologists, geographers, historians, eco-philosophers, lawyers and others are re-situating humanity within nature, and extending subjectivity to nature (see, for example, Graham, 2011; Ingold, 2000; Latour, 2001 [1993]; Manning et al., 2004; Mathews, 1994; Mitchell, 2002; Robin, 2007; Rose, 1996). From this position, we are not taking a view of the world, but 'taking a view in it' (Ingold, 2000: 42). Within this world, we acknowledge our lives are in connection with multitudes of other beings, and we can better foreground these ecological relationships in our decision making. This disciplinary re-think is both a response to separation thinking, and a move towards more holistic or integrated thinking. This is also a move towards the knowledge tradition of country and an expanded connectivity. 
Country and ecology relate as knowledge traditions because they explicitly acknowledge the interdependence of life, albeit these are expressed differently. Because Indigenous people have an expanded notion of connectivity, they make connections that cannot be categorised as just an energy exchange. For example, Indigenous people repeatedly identify the role of water as a life force, but link that to ceremony, song, protocols and survival (Yu, 1999). In Arnhem Land, major regional ceremonies ensure the arrival of the wet season, and thus the good health of the participants through the multiplication of species and continued opportunities for good hunting (Taylor, this volume). Walmajari people in south west Kimberley also conduct ceremonies to ensure the rains come, linking the rains with invisible seeds that produce the animal species associated with water, such as goanna, frogs, land crabs, fresh water eels, turtle, fish, and ducks (Sullivan and others, this volume). Conversations about the unique ecologies and species of particular places provide an important site of engagement between Indigenous people and ecologists. In specific places there are many unique plants and animals, which are described as endemic by ecologists. Indigenous peoples' often very detailed and intimate knowledge about these species is based in thousands of years of observation, experimentation and teaching (Horstman and Wightman, 2001: 99).

Indigenous peoples' ecological knowledge is sometimes described in western scientific discourses as 'ethnoscience' or 'non-science', and treated as inventory knowledge similar to eighteenth century botany (Braun, 2002: 307, fn 1). This hierarchical relationship between knowledges is aided by the presumed universal approach of western science. By presuming universalism, western science challenges the validity of other local knowledge systems, whilst denying its own cultural origins in Euro-American capitalist understandings of the world (Sillitoe, 2007: 13). As described above in relation to ecology, all 'sciences' have socio-political, cultural and historical contexts that inform how knowledge is prioritised, sought and interpreted. Understanding the cultural context of different sciences is important so that Indigenous peoples' knowledges are not described (and then dismissed) as 'cultural'; that is, as context specific and not capable of communicating in and across other contexts.

The positioning of Indigenous peoples and their knowledges as 'cultural' or 'traditional' within (presumed universal) Eurocentric knowledge frameworks has implications not just for understanding their ecological knowledge, but also for the recognition of their rights. Narrow legal interpretations of 'tradition' have had a profound effect on who is recognised as having native title, and what those native title rights are. Because of the close relationships between country and ecology, ecological considerations are either explicitly or implicitly part of these encounters. 


\section{Native titles}

Native title recognises Indigenous peoples' laws, customs and connections with their lands and waters. Native title was recognised in the 1992 High Court Mabo decision (Mabo v Queensland [No 2], 1992), although the Court had previously acknowledged the distinct legal rights of Indigenous peoples in country. ${ }^{2}$ Following Mabo, native title was enacted in Federal legislation as the Native Title Act 1993 (Cth) (NTA). The NTA establishes a system for recognising native title, making native title applications, forming native title agreements, and for holding and managing native title rights. Native title rights and interests are unique for each native title holding group, as based in their laws and customs, and reflecting the diversity of Indigenous peoples' cultural, legal and political traditions. However, native title is not the same as those laws and customs, rather it is the recognition of them. In this recognition, native title brings with it a sweep of intercultural interactions, intricacies and ideologies around the law, Indigenous peoples' cultures and traditions, and separation thinking and connectivity thinking.

The ideology of 'tradition' has played a large role in the recognition of native title, Indigenous peoples' rights, and their intersection with issues of ecology and economy. Native title statutory and common law have defined native title as traditional. Indigenous peoples changes to and adaptations of their laws and customs are permissible so long as the laws and customs remain traditional enough. For example, whether Indigenous people use a gun or a spear to go hunting is not at issue, but whether they identify as a society of people with traditional laws and customs is. This emphasis on tradition is fraught because traditions are socially constituted in both contemporary place and time. Whilst the defining feature of traditions is a reference to continuity with the past, traditions are constantly constructed and reconstructed to serve contemporary purposes (Otto and Pedersen, 2005: 11, 31).

The most well known native title determination that hinged on different interpretations of tradition is Yorta Yorta (Yorta Yorta Aboriginal Community $v$ the State of Victoria and Ors, 1998, unreported). This decision related to Yorta Yorta contemporary expressions of looking after country, and their participation in economic life. Yorta Yorta country is river country on the border of southern New South Wales and northern Victoria. At their native title trial, Yorta Yorta talked about cultural heritage and national resource management as part of being traditional owners of country (Muir and Morgan, 2002: 5). Another part of their evidence of connection was an 1881 petition requesting the Governor of New South Wales for some of their traditional country so that they could become

2 With respect to Gunditjmara people, in Onus v Alcoa of Australia Ltd (1981) 149 CLR 27 (Weir, 2009b: 13). 
independent farmers. However, in the Federal Court decision, Justice Olney determined that the Yorta Yorta had 'abandoned' their native title traditions, and that environmental conservation was not Yorta Yorta culture (paras 126, 128). The adoption of commercial farming by the Yorta Yorta was antithetical to their status as traditional owners (Strelein, 2009: 75). Olney found that the Yorta Yorta's traditional laws and customs had been 'washed away by the tide of history'. ${ }^{3}$ Such is the influence of 'tradition' on Indigenous identity, that Indigenous people who seek to make a commercial livelihood from country, as the Yorta Yorta petitioned for in 1881, are not only being untraditional, they are not eligible for Indigenous rights, and their status as an authentic Indigenous person is challenged (Weir, 2009a: 23).

It is native title's narrow understanding of tradition which frames native title as uneconomic (Strelein and Weir, 2009). Whilst there are a few exceptions, in general the lists of native title rights and interests recognised in native title determinations do not include economic or commercial rights and interests. Aboriginal people somehow exist outside the modern economic space. Their lived reality is very different, including their native title work. For example, native title holders negotiate access to their lands and waters with mining and exploration companies in a very commercial context. Indigenous people leverage their right to negotiate for economic benefits for their native title corporation (O'Faircheallaigh, 2007).

The debate on being traditional and being Indigenous engages with ecological issues through western notions of Indigenous people as noble savages living in harmony with nature, and untouched by civilisation (Hames, 2007). Indigenous people are exempted from the nature-society hyper-separation, and instead collapsed into nature as part of the fauna and flora (Braun, 2002; Langton, 1995). The simplistic matching of Indigenous and conservation agendas is evident in environmental forums when Indigenous people either exploit this notion, or challenge it as being prejudicial. These tensions have been evident in the debate over the Wild Rivers Act 2005 (Qld), which has placed environmental protection measures on rivers in Cape York, and the impact of this legislation on native title rights and interests. This is also evident in the decision by Woodside Energy Ltd to locate a gas processing facility at Walmadan (James Price Point) north of Broome in the Kimberley, which will bring industrial development to areas of immense natural and cultural heritage. The Kimberley and Cape York have a history of collaborations between environmental interests and Indigenous interests, but these working relationships have unraveled as expectations and priorities differ around Indigenous rights and conservation. Industrial capitalism has perpetuated the misalignment of the motivations of Indigenous people

3 Yorta Yorta Aboriginal Community $v$ the State of Victoria and Ors, 1998, unreported, para 19. This phrase was used repeatedly in the determination, see paras 3, 126, 129. 
and environmental groups, by entrenching ecological and economic priorities as oppositional (Weir, 2009a: 24-25). This relationship is being rethought in sustainability studies to identify synergies between economic, ecological and social goals.

In addition to ideologies of tradition, native title is strongly influenced by interpretations of statutory and common law. Native title is an intensely legalistic system, which has its own technical rules and self-reinforcing legal narrative (Ritter, 2010: 193). This governance context can have unpredictable outcomes. For example, the recognition of native title on national park and other reserved land tenures differs substantially between State and Territory jurisdictions (see also Bauman and Haynes, forthcoming). In New South Wales and Queensland non-exclusive native title rights have been recognised. However, in the 2002 High Court Ward (Western Australia $v$ Ward, 2002) decision for the Miriuwung and Gajerrong peoples, the Court found that native title rights did not survive the vesting provisions of most national parks in Western Australia (Strelein, 2009: 70). In the same Ward decision, the High Court found the opposite with respect to national parks in the Northern Territory. In the Territory, problems with the tenure and statute for Keep River National Park meant that its title was void - bringing the validity of all national parks in the Northern Territory into question. The Northern Territory government responded with a comprehensive agreement-making process to set up joint-management provisions with traditional owners for the majority of the Territory's national parks, irrespective of whether native title had been recognised at each particular park (Dillon and Westbury, 2007: 96-111). In Western Australia, traditional owners and native title holders have had to lobby for joint-management legislation to overcome the discriminatory effect of the state legislation. This is now starting to be addressed through amendments to State conservation legislation. ${ }^{4}$

The Yanner (Yanner $v$ Eaton, 1999) case provides another example of how native title court decisions are renegotiating environmental management in relation to the distinct legal rights of Indigenous peoples. In late 1994 Murrandoo Yanner killed two young estuarine crocodiles from Cliffdale Creek, which is in his country near the Gulf of Carpentaria in Queensland. He ate the crocodile meat together with other members of his clan. Estuarine crocodiles are a protected species under the Fauna Conservation Act 1974 (Qld). They are protected in Queensland because the crocodiles had been hunted to near extinction for their skins. Yanner was charged for breaching the Fauna Conservation Act, his defence was that he had native title rights to kill and eat the crocodiles. In 1999, the High Court upheld Yanner's native title rights. The justices determined

4 The Conservation Legislation Amendment Bill 2010 will amend the Conservation and Land Management Act 1984 to enable joint management arrangements between the Department of Environment and Conservation and other landowners, including Aboriginal people. 
that the government cannot own wildlife, it can only regulate wildlife and this regulation is not enough to extinguish native title. Yanner's native title rights to hunt crocodiles for domestic purposes had survived this regulation.

Both Ward and Yanner highlight how Indigenous peoples' native title rights and environmental policy intersect. Native title rights often survive on reserved lands, and Indigenous people have distinct rights to hunt, fish and gather native species. Environmentalists have lobbied for species protection and the reservation of protected areas as part of governments' responsibilities to respond to environmental issues such as the clearing of native forests and the loss of species diversity. Indigenous peoples' rights with respect to such lands and species are distinguished as distinct because they are distinctly different from other people in Australia - they have their own laws, traditions and customs in relation to Australia's lands and waters (Weir, 2009a: 115-116).

Beyond the legal framing of native title, Mabo has delivered a shift in societal attitudes to better recognise the distinct relationships between traditional owners and their country. For Yorta Yorta, despite their native title experience they continue to be recognised as the traditional owners of country. The Victorian government opposed their native title application, but soon after they signed a joint-management agreement with Yorta Yorta over the river red gum forest in the centre of Yorta Yorta country (Atkinson, 2004).

\section{Native title as environmental management}

The recognition of traditional owners in Australian society and government is delivering a greater involvement of Indigenous people in ecological issues, often through environmental partnerships with governments on native title, land rights, and public lands more generally.

Native title is increasingly part of the environmental management picture for Australia because of the sheer extent of its recognition. Over 1,195,935 square kilometres of land has been determined as native title, or about 15 per cent of Australia's land mass, and representing around 100 determinations. ${ }^{5}$ In addition, there remains a backlog of more than 350 native title applications awaiting determination by the courts. Much native title recognition has been in northern and 'remote' Australia, where native title determinations have been as large as 136,000 square kilometres in the case of the Martu people. In remote Australia native title is often recognised as exclusive possession. Determinations in settled

5 From 'Determinations of Native Title: as at 30 June 2011', <http://www.nntt.gov.au/Publications-AndResearch/Maps-and-Spatial-Reports/Documents/Quarterly\%20Maps/Determinations_map.pdf $>$ (accessed 30 August 2011). 
Australia are often non-exclusive possession, and recognised on much smaller pieces of land because of the land tenure history. Together with land rights lands and other Indigenous land holdings, this 'Indigenous Estate' comprises almost 20 per cent of Australia (Altman, Buchanan, Larsen, 2007).

The extent of the Indigenous Estate means that strategies designed to respond to national environmental issues must engage with native title holders and traditional owners. This includes climate change adaptation and mitigation, our priorities for water, and our management of invasive pests, diseases and weeds. Native title land holdings also have implications for the environmental management of particular places, which is nationally important as they include many areas of high conservation and biodiversity significance (Altman et al., 2007: 14). Collaboration is central where non-exclusive native title possession is recognised on public lands, such as national parks and reserved lands, state forests, stock routes, and pastoral lease lands. Where exclusive native title is recognised, native title holders arguably carry the responsibilities of land holders as deemed under the various land acts of the States and Territories. ${ }^{6}$

There are several native title governance bodies that Indigenous people work with as part of applying for and holding native title. Native title applicants work closely with Native Title Representative Bodies and Native Title Service Providers to bring together evidence of their native title, as based in their traditional laws and customs, and to reach a native title determination either through litigation or mediation. If native title is recognised, the native title holders are required by the NTA to set up a Registered Native Title Body Corporate (RNTBC) to manage their native title rights and interests, and to provide a legal entity for other people who wish to do business on native title land (AGDSC 2006; Weir, 2007). There are now about 80 RNTBCs in Australia. ${ }^{7}$ These RNTBCs are the key native title governing body for native title lands and waters, including land and water issues, community services, economic development, and more. They continue to receive assistance from Native Title Representative Bodies and Native Title Service Providers in matters such as native title agreements (known as Indigenous Land Use Agreements) and future act negotiations. Future acts are procedural rights to be notified, consulted or involved in negotiations with respect to certain development activities. A future act could be the development of a mine, a house or a national park.

\footnotetext{
6 This legal position is currently being examined in a research project into weeds management on native title lands, which is being undertaken at the Australian Institute of Aboriginal and Torres Strait Islander Studies, funded by the Rural Industries and Research and Development Corporation.

7 RNTBCs are also known as PBCs - Prescribed Bodies Corporate, as this is the name they are known by prior to their registration after a successful native title determination.
} 
RNTBCs do not receive operational funding, and are advised to seek funding from government and private grant monies (AGDSC, 2006). This has presented numerous challenges for RNTBCs (Bauman and Tran 2007; Bauman and Ganesharajah 2009; Weir, 2011), however an important although limited source of funds is grant monies for environmental management. For example, the Federal Government's Working on Country program provides funding for Indigenous people to work as rangers on their own land, water and sea management projects. There is also an emerging trend for collaborations with the Federal Government's Indigenous Protected Area program. The Indigenous Protected Area program establishes reserved lands governed by Indigenous people on Indigenous held and some public lands (Bauman and Smyth, 2007). In exchange for resources such as staff wages and a vehicle, native title holders agree to certain environmental protections and outcomes on their land. The resources resulting from these collaborations are of immense value for underresourced RNTBCs, who are sometimes also supported by land and sea units based within Native Title Representative Bodies. However, matching native title with environmental land tenures may have unintended consequences, including perhaps limiting their eligibility to participate in carbon economies (Gerrard, this volume).

Both the Indigenous Protected Area and Working on Country programs recognise the importance of Indigenous peoples' land holdings for environmental management, as well as Indigenous peoples' 'caring for country'. Caring for country is a term used to describe Indigenous peoples' land and sea management. As discussed above, there is a reciprocal relationship between people and country. This is reflected in the familiar saying by Indigenous people that if you look after the country, the country will look after you' (Griffiths and Kinnane, 2010: iii, 3). This is supported by research into the health and other benefits of caring for country activities (Burgess et al., 2005; Garnett and Sithole, 2007). Government literature from the Indigenous Protected Area and Working on Country programs also relate caring for country to broader outcomes in terms of supporting Indigenous people to live on country, with intergenerational benefits such as keeping culture strong, meaningful economic opportunities, health, education and social cohesion (DEWHA, 2009; DEWR, 2007).

The importance of environmental jobs in enabling traditional owners to continue to live on country is discussed by Luke Taylor (Chapter 2, this volume). Taylor draws on conversations with Kuninjku language speaker Ivan Namirrkki, to describe one man's connection to his country, an outstation in a stringybark forest in western Arnhem Land. Taylor relates Namirrkki's appreciation of country to Kuninjku concepts of personhood, sociality, power, health, and aesthetic experience. Namirrkki's outstation is in the country of another Kuninjku clan, not his own, and his negotiated rights to live here are an acknowledgement of 
his personal historical circumstances that led to his knowledge of this country. It is a good example of the dynamic contemporary relationships between people and country. Yet Namirrkki's outstation life is recast as anachronistic in national debates framed by the participation of Aboriginal people in the national economy. Taylor counters this with examples of Aboriginal people taking advantage of the on-country enterprises available to them. Through these kinds of work effort and economic opportunities, Aboriginal people continue to articulate their concerns to nurture country whilst also connecting with western modes of action and thinking.

Patrick Sullivan, and co-authors Hanson Boxer (Pampila), Warford Bujiman (Pajiman), and Doug Moor (Kordidi) go so far as to say that environmental collaborations are perhaps more important than native title recognition (Chapter 3 , this volume). The authors describe the importance of water to Walmajari people of the Great Sandy Desert. These waters are living waters, intimately linked with the kalpurtu who are the very first beings. The importance of the wet season in providing food and water is evident in the energy Walmajari invest in rain making ceremonies. The authors describe the comfort, homeliness and sociality of various billabongs and soaks, used cyclically by people through the seasons. This is a holistic cultural system which combines spiritual practices and the use of local knowledge to look after country. The authors question whether native title could do justice to these beliefs, or protect their connection to their local water sources which have suffered environmental degradation from pastoral activities. They note that native title recognition itself does not provide the necessary resources and organisation to revitalise the land. Instead, what is needed is a resourced 'two-way' alignment of priorities between settler and Aboriginal stakeholders, to introduce conservation measures and renew cultural activities.

Yolngu people from north-east Arnhem Land have developed the term 'two ways management' as a counterpoint to the dominance of non-Indigenous science in natural resource management projects. Samantha Muller discusses the Yolngu approach with respect to the Yellow Crazy Ant Eradication Program, a project which Yolngu people have initiated in partnership with various government and non-government participants (Chapter 4, this volume). Twoways management is intended to be collaborative across Indigenous and nonIndigenous ways of knowing country. But in the Crazy Ant project, ontological, logistical, cultural and fiscal challenges thwart this intention. At base, there are different perspectives on the project itself; whether it is just about an ant, or about the meeting and exchange of two knowledge systems. The non-Indigenous senior scientist admits that he cannot see the relationship between an invasive introduced pest and Yolngu knowledge. Muller argues that to improve the legibility of ideas across cultures we need to better develop a lingua franca - a 
common language - to ensure that such partnerships are meaningful for both parties. Muller also identifies the lack of equal resourcing as a key inhibiting factor in these culturally rich environmental collaborations.

Finding common ground in environmental issues is a theme in Chapter 5, written by myself, Roy Stone and Mervyn Mulardy Jnr. The Chapter documents an engagement between native title, water management, and a large scale cotton proposal in the West Kimberley south of Broome. This development proposal prompted research into the different values held in groundwater that had been identified for future agricultural consumption. What is unique about this water planning research is the methodology. The joint cultural and ecological fieldwork revealed the common ground held between Indigenous and hydroecological knowledge, thereby facilitating the immediate relevance of Karajarri water knowledge to contemporary water management and planning. This relevance is not reflected in Karajarri native title. Karajarri provided their intimate knowledge of groundwater as native title evidence, but their consent determination did not include native title rights or interests to that water.

Lee Godden (Chapter 6, this volume) considers the growing trend of agreement making with Indigenous people, and how such agreements co-locate native title and ecology within legal, economic and social framings. Agreement making has been adopted across the native title system as a way of managing the problems with the rules of native title, as formalised in Indigenous Land Use Agreements. Godden relates this agreement making trend to wider structural changes precipitated by global processes and ideological influences. One of these structural changes is the movement of governments away from delivering goods and services, towards using contracts to govern many areas for political, social and economic life. Often ecology is explicitly manifested in these agreements as joint-management, but it is more common that ecological concerns are diffused through the agreement, such as the stewardship responsibilities that come with native title recognition over pastoral leases. Godden considers how these environmental collaborations are currently being reworked through the increasing use of market tools to address environmental issues, and is concerned that ecology and equity are being displaced by the economic context of efficiency and development.

This 'market environmentalism' is part of the reinvention of conservation using market tools, and perhaps its best known example is carbon trading in response to climate change. Carbon trading is a key strategy to reduce the increase of greenhouse gases in the atmosphere, and thereby mitigate the effects of climate change. In Australia, climate change will alter local ecologies as rain patterns change, sea levels rise, and plant and animal species move south. In the north, the potential for increased rain and cyclonic activity will challenge living conditions in remote communities (Green, Jackson and Morrison, 2010). Climate 
change is not just changing how we frame our environmental priorities, but has brought ecological considerations into the centre of industrial and political agendas.

Emily Gerrard (Chapter 7, this volume) identifies that Indigenous people have a special interest in climate change because of their unique relationships with country, and their specialised knowledge. However, climate change related laws, regulations and markets have the potential to further decrease or limit Indigenous peoples' rights and interests in country and its resources, either through the extinguishment of native title or restricting access rights to land and resources. Gerrard argues that the international principle of 'common but differentiated responsibility' has relevance here in a national context. This principle encourages a shared responsibility to climate change while protecting certain populations from a disproportionate burden of meeting mitigation and adaptation obligations. Gerrard makes it clear that this substantive equality approach to climate change requires action in terms of legal foundations and policy incentives to support Indigenous people to be responsive to the carbon constrained world.

There are economic opportunities in market environmentalism, conservation, environmental management, and so forth for on-country enterprises, which will support the viability of Indigenous people living and working on country. But climate change and ecological degradation are not just economic opportunities, they are a wake-up call to rethink how we can live on this planet. Human activities have become so influential on ecosystems that they define our current geological epoch.

Part of ensuring that Australia's land and water management regimes recalibrate to sustain ecological relationships is to learn from and work with Indigenous people. However, it has taken a long time for law and policy to begin recognising Indigenous peoples' governance arrangements, legal rights, and intellectual approaches to living with and looking after country. The chapters in this book give examples of the knowledge and approaches traditional owners bring to country, and how to better manage the interface between Indigenous and nonIndigenous epistemologies and ways of relating to country. Contentions over meaning, knowledge, and authority will persist, but they should not prevail to undermine the goal of sustaining life. 


\section{References}

Allen, TFH and TW Hoekstra 1992, Toward a Unified Ecology, Columbia University Press, New York.

Altman, J, G Buchanan and L Larson 2007, The Environmental Significance of the Indigenous Estate: Natural Resource Management as Economic Development in Remote Australia, CAEPR Discussion Paper No. 286/2007, Centre for Aboriginal Economic Policy Research, Australian National University, Canberra.

Atkinson, H 2004, 'Yorta Yorta Co-operative Land Management Agreement: impact on the Yorta Yorta Nation', Indigenous Law Bulletin 6(5): 23-25.

Attorney General's Department Steering Committee (AGDSC) 2006, Structures and Processes of Prescribed Bodies Corporate, Attorney General's Department, Canberra.

AGDSC - see Attorney General's Department Steering Committee

Bauman T and C Ganesharajah 2009, Second National Prescribed Bodies Corporate Meeting: Issues and Outcomes, Melbourne 2 June 2009, Native Title Research Report, Australian Institute of Aboriginal and Torres Strait Islander Studies (AIATSIS), Canberra.

Bauman, $\mathrm{T}$ and $\mathrm{C}$ Haynes (in review), 'Joint management and native title in Australian conservation areas: process, structure and partnership', AIATSIS Discussion Paper.

Bauman, T and D Smyth 2007, Indigenous Partnerships in Protected Area Management in Australia: Three Case Studies, AIATSIS in association with the Australian Collaboration and the Poola Foundation (Tom Kantor fund).

Bauman T and T Tran 2007, First National Prescribed Bodies Corporate Meeting: Issues and Outcomes, Canberra 11-13 April 2007, Native Title Research Report, AIATSIS, Canberra.

Braun, B 2002, The Intemperate Rainforest: Nature, Culture, and Power on Canada's West Coast, University of Minnesota Press, Minneapolis and London.

Burgess, P, FH Johnston, DMJS Bowman and PJ Whitehead 2005, 'Healthy country: healthy people? Exploring the health benefits of Indigenous natural resource management', Australian and New Zealand Journal of Public Health 29(2): 117. 
Country, Native Title and Ecology

Campese, J, T Sunderland, T Greiber and G Oviedo (eds) 2009, Exploring Issues and Opportunities in Rights Based Approaches to Conservation, CIFOR, IUCN and CEESP, Bogor, Indonesia: 123-140.

Department of the Environment, Water, Heritage and the Arts (DEWHA) 2009, Working on Country - A Retrospective 2007 - 2008, Department of the Environment, Water, Heritage and the Arts, Canberra.

DEWHA - see Department of the Environment, Water, Heritage and the Arts

Department of Environment and Water Resources (DEWR) 2007, Growing Up Strong: The First 10 years of Indigenous Protected Areas in Australia, Department of the Environment and Water Resources, Canberra.

DEWR - see Department of Environment and Water Resources

Dillon, C and ND Westbury 2007, Beyond Humbug: Transforming Government Engagement with Indigenous Australia, Seaview Press, West Lakes, South Australia.

Egerton, FN 1973, 'Changing concepts of the balance of nature', Quarterly Review of Biology 48: 322-350.

Garnett, S and B Sithole 2007, Sustainable Northern Landscapes and the Nexus with Indigenous Health: Healthy Country, Healthy People, Land and Water Australia.

Graham, N 2011, Lawscape: Property, Environment, Law, Routledge, Abingdon, United Kingdom.

Green, D, S Jackson and J Morrison (eds) 2010, Risks from Climate Change to Indigenous Communities in the Tropical North of Australia, Department of Climate Change and Energy Efficiency, Canberra.

Griffiths, S and S Kinnane, 2010, Kimberley Aboriginal Caring for Country Planhealthy country, healthy people, report prepared for the Kimberley Language Resource Centre, Halls Creek.

Hames, R 2007, 'The ecologically noble savage debate', Annual Review of Anthropology 36: 177-190.

Horstman, M and G Wightman 2001, 'Karpati ecology: recognition of Aboriginal ecological knowledge and its application to management in north-western Australia', Ecological Management and Restoration 2(2): 99-109.

Ingold, T 2000, The Perception of the Environment: Essays in Livelihood, Dwelling and Skill, Routledge, London. 
Kinnane, S 2002, 'Recurring visions of Australindia', in Country: Visions of Land and People in Western Australia, A Gaynor, M Trinca and A Haebich (eds), Western Australian Museum, Perth.

Langton, M 1995, 'Arts, wilderness and terra nullius', in Ecopolitics IX: Perspectives on Indigenous People's Management of Environment Resources, $\mathrm{R}$ Sultan (ed), Northern Land Council, Darwin.

- 2002, 'The edge of the sacred, the edge of death: sensual inscriptions', in Inscribed Landscapes: Marking and Making Place, B David and W Meredith (eds), University of Hawaii Press, Hawaii.

Latour, B 2001 [1993], We Have Never Been Modern, Harvard University Press, Cambridge.

Lindenmayer, DB 2007, On Borrowed Time: Australia's Environmental Crisis and What We Must Do About It, Penguin Books (in association with CSIRO Publishing), Camberwell.

O'Faircheallaigh, C 2007, 'Unreasonable and extraordinary constraints: native title, markets and the real economy', Australian Indigenous Law Review 11(3): 18-42.

Manning, AD, DB Lindenmayer and HA Nix 2004, 'Continua and Umwelt: novel perspectives on viewing landscapes', Oikos 104(3): 621-628.

Mathews, F 1994, The Ecological Self, Routledge, London.

Mitchell, T 2002 Rule of Experts: Egypt, Techno-politics, Modernity, University of California Press, Berkeley and Los Angeles.

Muir, J and M Morgan 2002, 'Yorta Yorta: the community's perspective on the treatment of oral history', in Through a Smoky Mirror: History and Native Title, M Paul and G Gray (eds), Aboriginal Studies Press, Canberra.

Otto, T and P Pedersen 2005, 'Disentangling traditions: culture, agency and power', in Tradition and Agency: Tracing Cultural Continuity and Invention, $\mathrm{T}$ Otto and P Pedersen (eds), Aarhus University Press, Denmark.

Plumwood, V 2002 [1993], Feminism and the Mastery of Nature, Routledge, London and New York.

Ritter, D 2010, 'The ideological foundations of arguments about native title', Australian Journal of Political Science 45(2): 191-207.

Robin, L 2007, How a Continent Created a Nation, University of New South Wales Press, Sydney. 
Country, Native Title and Ecology

Rose, DB 1996, Nourishing Terrains: Australian Aboriginal Views of Landscape and wilderness, Australian Heritage Commission, Canberra.

- 2000 [1992], Dingo Makes Us Human; Life and Land in an Australian Aboriginal Culture, Cambridge University Press, Cambridge.

Sillitoe, P 2007, 'Local science vs. global science: an overview', in Local Science vs. Global Science: Approaches to Indigenous Knowledge in International Development, P Sillitoe (ed), Berghahn Books, New York.

Smith, BR 2005, “We got our own management": local knowledge, government and development in Cape York Peninsula', Australian Aboriginal Studies 2005(2): 4-15.

Stanner, WEH (ed) 1989 [1963], On Aboriginal Religion, University of Sydney, Sydney.

Strelein, L 2009, Compromised Jurisprudence: Native Title Cases since Mabo, 2nd edition, Aboriginal Studies Press, Canberra.

- and JK Weir 2009, 'Conservation and human rights in the context of native title in Australia', in Exploring Issues and Opportunities in Rights Based Approaches to Conservation, J Campese, T Sunderland, T Greiber, and G Oviedo (eds), CIFOR, IUCN and CEESP, Bogor, Indonesia.

Sutton, P 1995, Country: Aboriginal Boundaries and Land Ownership in Australia, Aboriginal History Monograph no 3, The Australian National University, Canberra.

Weir, JK 2007, 'Native title and governance: The emerging corporate sector prescribed for native title holders', Land, Rights, Laws: Issues of Native Title 3(9): $1-16$.

— 2008, 'Connectivity', Australian Humanities Review 45: 153-164.

- 2009a, Murray River Country: An Ecological Dialogue with Traditional Owners, Aboriginal Studies Press, Canberra.

- 2009b, The Gunditjmara Land Justice Story, Native Title Research Unit, AIATSIS, Canberra.

- 2011, Karajarri: A West Kimberley Experience in Managing Native Title, Discussion Paper, Native Title Research Unit, AIATSIS, Canberra.

Worster, D 2008 [1997], Nature's Economy: A History of Ecological Ideas, 2nd edition, Cambridge University Press, Cambridge. 
Yu, S 1999, Ngapa Kunangkul: Living Water. Report on the Indigenous Cultural Values of Groundwater in the La Grange Sub-basin, prepared for the Water and Rivers Commission, University of Western Australia, Perth.

\section{Cases}

Mabo v Queensland [No 2] (1992) 175 CLR 1

Onus $v$ Alcoa of Australia Ltd (1981) 149 CLR 27

Western Australia v Ward [2002] 213 CLR 1 (8 August 2002)

Yanner v Eaton 1999201 CLR 351

Yorta Yorta Aboriginal Community $v$ the State of Victoria and Ors [1998 unreported]

\section{Legislation}

Fauna Conservation Act 1974 (Qld)

Native Title Act 1993 (Cth)

Wild Rivers Act 2005 (Qld)

Conservation and Land Management Act 1984 (WA) 